Vantage: Journal of Thematic Analysis

ISSN: 2582-7391

A Multidisciplinary Publication of Centre for Research, Maitreyi College, University of Delhi

October 2021, Volume 2, Issue 2

Review Article

\title{
Safe Grain Storage- Post Harvest Technology: An Indian Perspective
}

Rita Rath, Ranjana Saxena*, Neeraja Sood, and Sadhna Gupta

Department of Zoology, Dyal Singh College, University of Delhi-110003, India.

*Correspondence: ranjana.saxena@ dsc.du.ac.in

\begin{abstract}
Due to green revolution and technological advancement in crop production, India has attained sufficiency in food grain productivity, yet a large population in our country goes hungry. The major reason for this is the postharvest losses that occur during storage, procurement and distribution. Factors such as improper and inadequate storage facilities, climatic conditions, ineffective management policies lead to physical, chemical and biological deterioration of food grains. Abiotic factors such as grain moisture content, temperature, initial grain condition and aeration system are crucial considerations for safe storage. Biological deterioration and losses due to fungi, mites, insects, birds and rodents are also significant. In India, Food Corporation of India (FCI) is the nodal agency, under the Ministry of consumer affairs, responsible for procurement of food grains at minimum support price (MSP), movement of produce to deficit regions, public distribution system (PDS) and maintenance of buffer stocks. Government of India constituted a high-level Shanta Kumar Committee in 2014 to recommend ways to rationalize and minimize postharvest losses, in addition to the already existing government policies. Futuristic approach to prevent these losses are to have bold and proactive reforms in India's grain management systems by implementing the recommendations of the Committee, using appropriate storage protocols, continuing subsidy only to the poor under Antyodaya Anna Yojna (AAY), controlling the subsidized grain distribution under NFSA (National Food Security Act-2013), intervention of private sectors and liquidation of stocks to contain inflation.
\end{abstract}

Keywords: Storage loss, storage facilities, FCI, AAY, NFSA, private sector 


\section{INTRODUCTION}

From a food importing country in 1960, India has today become self-reliant in food grain productivity (Sarma, 1978), but not in terms of its availability. This achievement of sufficiency in productivity, however, presents challenges in managing the surplus production. India had a record production of 291.95 million metric ton of food grains in 2019-2020 (General Survey of Directorate of Economics and Statistics, Ministry of Agriculture, 2020). However, as per the estimates of Food and Agriculture Organization, losses of up to $40 \%$ were recorded in India in that particular year. As per Food Corporation of India's assessment, 10-15\%losses have been attributed to postharvest factors (National Academy of Agricultural Sciences Report, 2019-20). As much as 1.95 lakh MT of food grains was known to be wasted in India between 2005 and 2018. According to Food and Agriculture Organization, produce worth $\$ 14$ billion is damaged annually. It is a paradox that millions go hungry in India everyday while food goes waste. Considering whatever estimates may be correct, this is a substantial amount which mandates proper food grain management after harvest and hence during storage, till it reaches the consumers. The challenges faced in India regarding food grain storage are manifolds viz inadequate and low-quality storage facilities, health issues caused due to mycotoxins released by fungal infestation, excretory wastes of biological organisms, losses by insects, mites, rodents, birds, human theft, pilferage and spillage.

\section{"A GRAIN SAVED IS A GRAIN PRODUCED"}

The above statement needs to be the motto of our country where, in spite of sufficient production of food grains a large population goes hungry. India ranked at $102^{\text {nd }}$ position out of 117 in the global hunger index of 2019 and $94^{\text {th }}$ out of 132 in 2020 . Improper storage and faulty management practices are the major causes of postharvest losses. According to a report by National Academy of Agricultural Sciences in 2019-2020, out of 291.95 MMT of cereals produced that year, 4.6 to $6.0 \%$ was lost during storage. Losses during storage are associated with spillage; fungal, mites, insect, rodent and bird attacks and pilferage, in addition to the other abiotic factors. This necessitates the implementation of proper and scientific Post Harvest Technologies to prevent such food grain losses. 
Post-Harvest Technology is a science and technology to protect, conserve, process, package, distribute, market or utilize agricultural products after their harvesting till the time it reaches the consumer or end user. This process may require variable periods of storage at different places or locations starting from the farmer level (producer) to the government agencies (as storer or distributors, etc.), to the consumer. It is during this time of storage that losses occur due to lack of proper storage facilities and management technologies.

There is a need to store food grains after harvesting for numerous reasons. At the farmer level, it needs to be stored from the time of harvest till it is sold to the government or in the market, or stored till the next growing season to be utilized for seed purposes or stored for self-consumption till next harvesting season. At the government level it is stored for the purpose of distribution to fulfill the food demand of the nation through the Public Distribution System, or for the maintenance of the buffer stocks for overcoming situations of emergencies or calamities resulting in food shortages or for exporting the surplus produce. For this, food grains are stored for variable periods necessitating efficient storage facilities and technologies.

\section{FACTORS AFFECTING FOODGRAINS DURING STORAGE}

Deterioration of food grains is a cumulative result of several associated management factors such as moisture content of food grains, initial grain condition, temperature, moisture migration and aeration (Jones \& Shelton, 1994; Athanassiou, 2015). Biological activities of stored grain pests are also influenced by a host of environmental factors (Hagstrum \& Milliken, 1988; Subramanyam \& Hagstrum, 1993; Honet et al., 2002).

\section{ABIOTIC FACTORS}

\section{i. Moisture Content}

In general, it is considered that a food grain with a moisture content of less than $8 \%$ is suitable for safe storage. Any moisture content above this exposes the food grains to deterioration due to fungi, mites, insects, or biochemical degradation. To prevent this deterioration, food grains should be dried to ensure that the moisture content is brought down to the desired level for safe storage. These optimal moisture content levels for safe storage may slightly vary from grain to grain as shown in Table 1 (Hall, 1980; 
Hellavang, 1990; Thompson \& Shelton, 1993; Sisman \& Delibas, 2005; Sisman, 2005). There are various indigenous and mechanized processes by which drying of the food grains can be done. In a country like ours, sun drying is one of the cheapest and effective method as sunlight is available in plenty in most parts of our country and mostly throughout the year. Where sunlight is limited, special drying methods/ techniques like using hot air, grain dryers, etc. need to be adopted (FAO Bulletin, 1987). The grain moisture content to a large extent is also dependent on the relative humidity of the atmosphere. Therefore, it is critical that atmospheric moisture pickup by grains during storage should also be prevented. This can be achieved by having or designing proper airtight storage facilities.

Table 1: Maximum recommended moisture content for the storage of different types of grains.

\begin{tabular}{|l|c|c|}
\hline \multirow{2}{*}{ Grain } & \multicolumn{2}{|c|}{ Moisture Content \% } \\
\cline { 2 - 3 } & $\begin{array}{c}\text { Short Term } \\
\text { (less than 6 months) }\end{array}$ & $\begin{array}{c}\text { Long Term } \\
\text { (more than 6 months) }\end{array}$ \\
\hline Barley & 14 & 12 \\
\hline Corn & 15.5 & 13 \\
\hline Beans & 16 & 13 \\
\hline Millet & 10 & 9 \\
\hline Rice & 13 & 12 \\
\hline Sorghum & 13.5 & 13 \\
\hline Non-oil Sunflower & 11 & 8 \\
\hline Oil Sunflower & 10 & 7 \\
\hline Flax seed & 9 & 13 \\
\hline Wheat & 14 & 13 \\
\hline Oats & 14 & 13 \\
\hline Pea-Cowpea & 15 & \\
\hline
\end{tabular}

\section{ii. Temperature}

Grain temperature should be maintained at desirable levels to avoid food grains from deterioration (Jones \& Shelton, 1994; Sisman \& Delibas, 2005). The biotic organisms require an optimal temperature in order to grow and multiply. The average lower 
developmental threshold (LDT) for Coleopteran insects is $14^{\circ} \mathrm{C}$ and Lepidopteran insects is $11.3^{\circ} \mathrm{C}$ (Subramanyam \& Hagstrum,1993; Stejskal et al., 2019). Temperatures in the range of $45-55^{\circ} \mathrm{C}$ or above are deleterious for the growth and survival of stored grain insect pests (Fields, 1992; Dosland et al., 2006). Therefore, storing food grains at temperatures below or above these temperatures help in prevention of these attacks. This can be achieved through aerating system or cold storage. At high temperatures grains sweat, leading to increase in the chances of infestation by insects and fungi. Moisture migration is a major concern in bulk storage leading to crusting and fungal growth (Sinha \& Wallace, 1966; Jones \& Shelton 1994; Mani et al., 2001; Sisman \& Delibas, 2005).

\section{iii. Aeration}

Provision for movement of air through the food grains during storage is also an essential consideration for designing the storage structures (Noyes et al., 2001; Navarro, 2012). This ensures that the desired moisture content and uniform temperature of food grains can be maintained during storage and thereby preventing the development of hotspots especially in bulk storage facilities (Hall, 1980; Brooker et al., 1992; Sisman, 2003; Sisman, 2005). Fumigation for preventing damage to food grains can also be done through this system (Kuzmanov \& Dimitrov, 2009).

\section{iv. Initial Grain Condition}

Storage is done to maintain the harvesting quality of products and not to improve it (Brooke et al., 1992; Jones \& Shelton, 1994). As grain quality cannot be improved during storage, good and high-quality grains should be chosen initially for storage to ensure good quality produce. Good quality grains compared to cracked and broken grains are easier to maintain in storage (Shelton et al., 1998; Sisman, 2003). Therefore, choosing the right quality of food grain for storage is very crucial.

The food grains during storage should be monitored regularly to assess the above criteria. It should be done at least every fortnightly during monsoon, spring, and fall and once a month in winter. This can help minimize the deterioration of food grains during storage (Shelton \& Thompson, 1993; Procter, 1994; Navarro, 2012). 


\section{BIOTIC FACTORS}

Fungi, mites, insects, rodents, and birds are important living organisms responsible for storage losses (Hagstrum \& Subramanyam, 2009; Stejskal et al., 2014; Stejskal et al., 2015). Fungi like Aspergillus and Penicillium affect the quality of grains by releasing mycotoxins thereby posing health hazards to the consumers (Piotrowska et al., 2013; Fleurat-Lessard, 2017; Hubert et al., 2018; Daou et al., 2021).

More than 1000 species of insects are known to attack food grains during storage, the majority being Coleopteran beetles (examples-Trogoderma, Rhizopertha, Sitophilus, Tribolium, Callosobruchus, etc.) and Lepidopteran moths (examples -Sitotroga, Corcyra, Plodia, etc.) (Khare, 1994). Insect pests may enter storage at various stages of processing of food grains; from agricultural fields, from threshing yards, during transit, or at storage (Pruthi \& Singh, 1950). Some of the common Indian storage insect pests and damage caused by them have been studied in depth (Srivastava \& Subramaniam, 2016; Tyagi et al., 2019). Mites such as Acarus, Aleuroglyphus, Cunaxa, Pyemotes, etc also cause storage losses (Hage-Hamsten \& Johansson, 1992; Nayak, 2006).

Considerable losses to the food grains during storage are also caused by rodents (examples- Rattus rattus, R. norwegicus, Mus musculus, Bandicoot bengalensis, Funambulus, Sciurus) and birds (examples - sparrows, pigeons, weavers, mynas, crow, dove, etc.) (especially in open storage facilities) (Smith, 1994). The excretory wastes of the insects, rodents, and birds cause qualitative deterioration in addition to quantitative losses due to their consumption. Pilferage and theft in unsecured storage places also add to the losses. Therefore, these organisms cause both indirect losses (by releasing toxins, excretory wastes) and direct losses by consuming grains leading to weight reduction, discoloration and foul odor.

\section{OTHER FACTORS}

Nonadherence to the Principle of first in and first out (FIFO) and delay in getting approvals for disposal of damaged stocks result in further losses. Hence, considering all these factors affecting food grains during storage and the need to store in different places, in different quantities, and for different periods, various storage facilities are in use traditionally, as well as being replaced by modern, scientifically more appropriate structures. 
Traditionally in India, at farmer's level, structures made of locally available materials of low cost and requiring low maintenance are prevalent in use (Said \& Pradhan, 2014) (Figure 1). These may be indoor or outdoor structures and may sometimes need to be constructed during every cropping season or maybe permanent structures. Some examples of such traditional structures prevalent in different parts of our country are: Morai - used mostly in eastern and southern regions in India, made of straw and bamboo strips; Bukhari- cylindrically shaped structure, made with mud alone or mud and bamboo; Mud Kothi - an indoor structure made up of mud clay, cow dung, straw in Rajasthan \& Himachal Pradesh; Kanaj - a cylindrical structure made of bamboo strips and plastered by mud; Bamboo baskets - used in Himachal Pradesh, Uttarakhand, Jharkhand \& Assam- weaved by bamboo strips and plastered with cow dung; Wooden boxes (sandhuk) used in Karnataka, Andhra Pradesh, M.P. \& Chattisgarh; Mataka - used in Haryana, U.P, Punjab, M.P, Jharkhand \& Bihar- a structure made up of sandy clay and is kept indoors; Mud and straw outdoor structures; bamboo and mud structures - in Assam known as gummi. Apart from these, metallic bins or drums; plastic bags; gunny bags, and jars are used for small quantities of domestic storage.

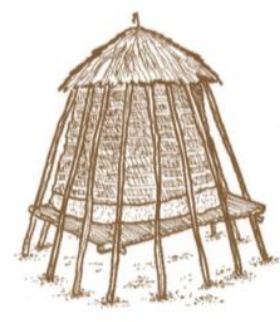

Mud plastered Structure

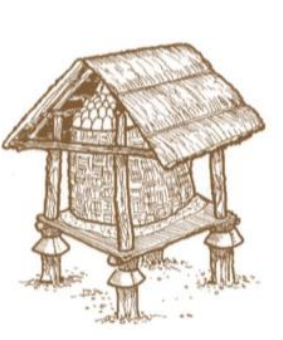

(1)

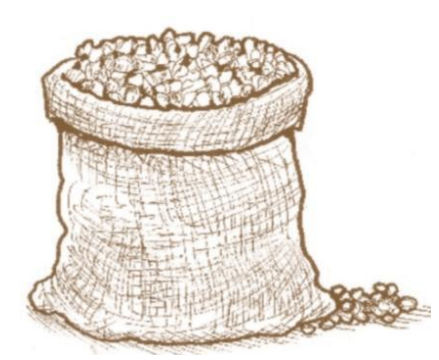

Gunny Bag

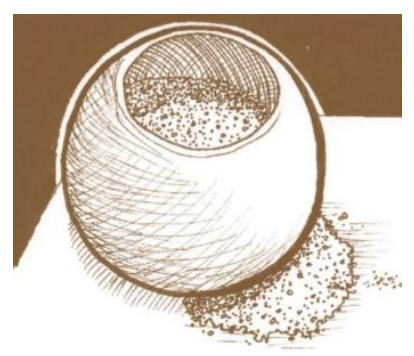

Earthen Pot

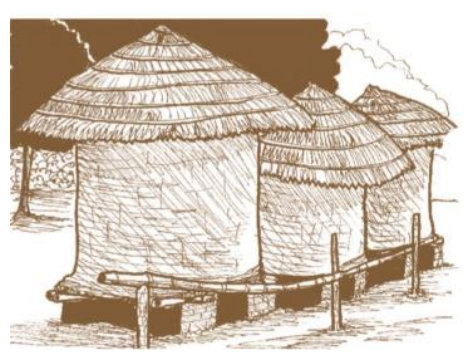

Straw Structures

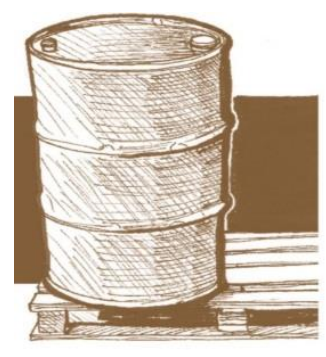

Metallic Bin

Figure 1: Few examples of traditional storage structures in use in India (sourcehttp://www.fao.org/3/ca1495en/CA1495EN.pdf License- CC BY- NC SA- 3.0 IGO) 
Most of these traditionally used structures have some shortcomings for long-term storage and some modifications need to be incorporated into their design for improving storage conditions. To overcome some of the drawbacks of these structures for safe storage, a more scientifically acceptable structure, at low cost, was designed at Indian Agricultural Research Institute (IARI), Pusa, New Delhi, known as Pusa bin using mud, brick, and polythene (Bhardwaj, 2014). At the Government level, both in the State (State warehousing Corporation- SWC) and the Center (Central Warehousing Corporation-CWC \& FCI) food grains are stored in Modern Scientific structures in bulk using Silos or in bags in godowns or sheds (Procter, 1994; Vidal et al., 2005).

\section{i. Silos}

These are mostly made from steel or reinforced cement concrete (RCC) (Figure 2). These could be shallow bins also known as squat silos or could be deep bins known as hopper bottom silos. Associated with these structures are other accessory facilities for the convenience of handling and movement of food grains.

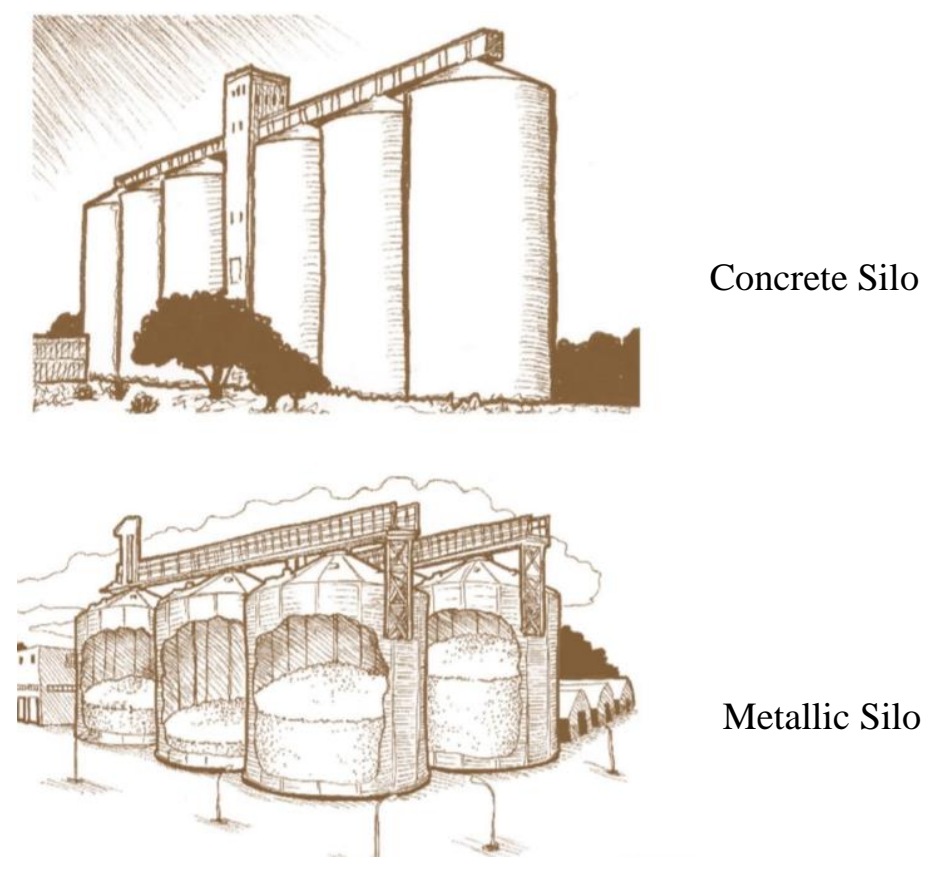

Figure 2: Silos (source- http://www.fao.org/3/ca1495en/CA1495EN.pdf License- CC BY- NC SA- 3.0 IGO)

\section{ii. Sheds or Godowns or Warehouses}

These are covered horizontal storage structures made of steel or corrugated sheets with flat concrete floors (Mishra, 2012) (Figure 3). Other accessories provided in such 
structures are the conveyor belts for mechanized movement of food grains in and out and aeration systems.

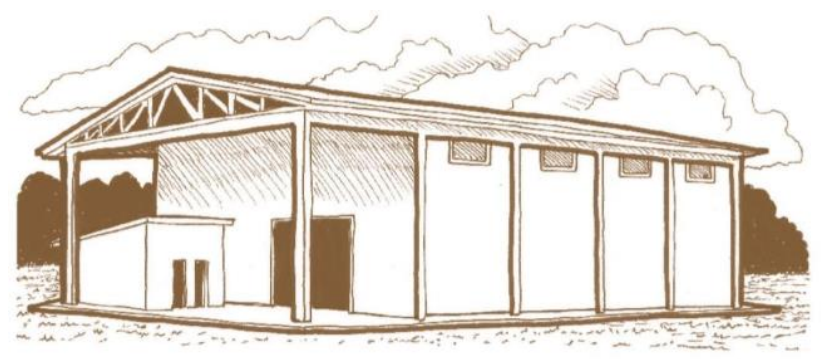

Figure 3: A warehouse (source- http://www.fao.org/3/ca1495en/CA1495EN.pdf License- CC BY- NC SA- 3.0 IGO)

\section{iii. Covered and Plinth (CAP)}

These are economical structures in which Plinth is made of cement and concrete and food grain bags are stacked in open and covered by polythene cover (Bhardwaj, 2015). However, these are not appropriate storage facilities for long term.

With this understanding of the problems and challenges faced by India during storage and the non-availability of adequate storage facilities, resulting in 10-15\% loss of food grains, it is clear that the adoption of better management practices and policies is required to prevent these losses (Bhardwaj \& Sharma, 2020). Spoilage losses can only be minimized by adopting proper storage conditions and management practices (Cloud \& Morey, 1980).

In India, Food Corporation of India (FCI) is the nodal agency, under the Ministry of Consumer Affairs, which is responsible for procurement, storage and distribution of food grains. Therefore, it becomes FCI's responsibility and obligation to accept and implement the already existing governmental initiatives/policies and Shanta Kumar Committee recommendations for safe storage of food grains. FCI should deploy latest scientific postharvest technologies and strictly follow the required protocols for storage.

For preventing storage losses, the Supreme Court (SC) in 2010 made an important observation and gave a ruling. The SC stated, "In a country where admittedly people are starving, it is a crime to waste even a single grain". Therefore, all efforts need to be made not to waste a single grain (PUCL vs ORS- 2010). 
Based on the SC observation, Government of India constituted a Shanta Kumar (former Chief Minister of Himachal Pradesh) Committee in 2014 to recommend reforms to improve FCI's operational efficiency and financial management. Some of their important recommendations were:

1. FCI should outsource food grain storaging to some northern and western states of India capable of handling food grains safely through SWC (State Warehousing Corporation or PEG (Private Entrepreneur Guarantee) and should itself focus on eastern and northeastern states of our country.

2. Use of more scientifically advanced storage structures with better mechanization in all silos / conventional storage facilities.

3. Covered and Plinth storage to be phased out and if at all to be used, should not be for more than three months storage.

4. Food grains should be transported in proper containers to reduce transit losses.

5. There should be changes in the food security laws to reduce subsidy beneficiaries from $67 \%$ of the population to $40 \%$ under the National Food Security Act-2013

6. For efficient and loss free transportation, there needs to be provision of rail connectivity and end to end computerization, enabling online tracking from the point of procurement to retail distribution.

7. Under Antyodaya Anna Yojna category subsidy to be given only to the poorest of the poor and the issue price is to be fixed at $50 \%$ of the procurement price for others.

Some of the already existing Governmental initiatives for food storage are:

1. National Food Security Act -2013 under which subsidy in food grains is provided to the poor.

2. Gramin Bhandaran Yojna- under this scheme subsidy is given for construction or renovation of rural godowns

3. Private Entrepreneur Guarantee (PEG) - this is a scheme awarded to some operators in Punjab, Delhi, Bihar, Assam and Karnataka based on PPP (Public Private Partnership) model. 
4. Joint venture with CWC and Indian railways facilitating the usage of railways vacant land for constructing Rail-side Warehousing Companies Limited.

5. Antyodaya Anna Yojna - 2000 (AAY) - is a scheme directed towards reducing hunger among the poorest segments of the Below Poverty Level (BPL) population by providing them ration at very low prices.

But despite these existing policies and initiatives a large population of our country still goes hungry. Apart from the main causes of storage losses, discussed above, in India, the other significant reasons for such losses are the reluctance of small-scale farmers to adopt scientific storage methods or technologies and the inadequacy of our National Agencies to cater to the problems of surplus grain supplied by farmers. The nonacceptance by farmers of the improved storage technologies, could partly be due to lack of knowledge or accessibility to these technologies. Therefore, the extension of research in this area to reach the farming community is of utmost importance (Hagstrum \& Athanassiou, 2019; Maity et al., 2020).

In India, in the last few decades, many governmental, non- governmental and private organizations have done research and studies for the development of new technologies for farmers (Kumar \& Kalita, 2017; Naveena et al., 2017). Based on these studies experts have advocated a holistic approach for safe storage of food grains which should be demand driven and have active farmers participation (Malek et al., 2017). In our country the food security depends on the subsistence farming, as $80 \%$ of the agricultural community comprises of marginal farmers (Dev, 2012). Therefore, prevention of losses at the farmers level should be a priority .

\section{FUTURE APPROACH/ WAY FORWARD}

There needs to be implementation of the above suggested reforms to achieve the goal of minimizing losses during storage. In our view, some of these approaches can be as follows:

1. Traditional storage structures which are used either at the farmer level or by the Government agencies, should be strengthened by use of new, improved and cheap scientific storage structures. At Government level, silos should be preferred over the gunny bags.

2. Development of proper implementable scientific protocols for storage. 
3. Research and development to be encouraged and continued in the field of adverse biotic and abiotic impact during storage. Regular monitoring of food grains during storage and damage control through fumigation should be practiced.

4. Data availability and accessibility should be provided through computerization and software integration throughout India, for obtaining information pertaining to production, demand, procurement, storage and retail distribution.

5. The policy of First in and first out needs to be strictly followed.

6. There should be proactive liquidation policy for excess buffer stocks which could help control inflation.

7. The subsidy policy needs to be continued for the poor under Antyodaya category but the price for others should be fixed at $50 \%$ of the procurement rate.

8. The subsidy benefit under the National Food Security Act-2013 should be limited to only $40 \%$ of the population from $67 \%$ which is the current percentage.

9. Involvement of Private Sectors in grain management needs to be encouraged and promoted.

\section{CONCLUSION}

In conclusion, it is clear, that there needs to be a strong proactive reform policy in the Grain Management System in India, which could lead to an extra annual saving of Rs. 50000 crores, in turn helping to reduce the fiscal deficit of the country, contain inflation and ensuring food reaches every individual of our population and no one in our country goes hungry. This would be a long way forward towards achieving the zero- hunger goal of the world towards sustainable development.

\section{ACKNOWLEDGEMENTS}

We acknowledge Dyal Singh College, University of Delhi for its continuous support, encouragement and motivation throughout the duration of preparation of this paper.

\section{CONFLICT OF INTEREST}

The authors declare no conflict of interest. 


\section{REFERENCES}

Athanassiou, C. G. (2015). Integrated protection of stored products: Sustainability in Practice. Journal of Stored Products Research, 64, 121-174. DOI:10.1016/j.jspr.2015.04.008

Bhardwaj, S. (2014). Grain storage structures for farmers. Popular Kheti, 2(2), 202-205.

Bhardwaj, S. (2015). Recent advances in cover and plinth (CAP) and on farm storage. International Journal of Farm Sciences, 5(2), 259-264.

Bhardwaj, S., \& Sharma, R. (2020). The challenges of grain storage: A review. International Journal of Farm Sciences, 10(2), 18-22. DOI:10.5958/2250$\underline{0499.2020 .00028 .2}$

Brooker, D. B., Bakker-Arkema, F. W., \& Hall, C. W. (1992). Drying and storage of Grains and oilseeds. New York: Van Nostrand Reinhold.

Cloud, H. A., \& Morey, R. V. (1980). Management of stored grain with aeration. Minnesota, USA. Retrieved from: https://agris.fao.org/agris-search/search.do? recordID=US19810705074

Daou, R., Joubrana, K., Maroun, R. G., Khabbaz, L. R., Ismail, A., \& Khoury, A. E. (2021). Mycotoxins factors influencing production and control strategies. AIMS Agriculture and Food, 6(1), 416-447. https://doi.org/10.3934/agrfood.2021025

Dev, S. M. (2012). Small farmers in India; Challenges and Opportunities. Retrieved from https://www.igidr.ac.in/pdf/publication/WP-2012-014.pdf

Dosland, O., Subhramanyam, B., Shepperd, K., \& Mahroof, R. (2006). Temperature modification for insect control. In: J.W. Heaps (Ed) Insect management for food storage and processing (Second Edition) pp 89-103.American Association of Cereal Chemists International, USA. https://doi.org/10.1016/b978-1-891127-46$\underline{5.50015-5}$

FAO (1987). On farm maize drying and storage in humid tropics. FAO Agricultural Services Bulletin no 40, Rome, Italy. Retrieved from https://books.google.co.in/books?id=b1y779RWiFYC\&pg=PP1\&lpg=PP1\&dq= on+farm+maize+drying+and+storage+in+hu+mid+tropics, + FAO+Agricultural+ bulletin+40\&source=bl\&ots=0nNHtqxJXI\&sig=ACfU3U1Sgb2AiN_aBWfbJdSfnsAX3HylA\&hl=en\&sa=X\&ved=2ahUKEwif8Y_not3zAhXCwjgGHT0 BGsQ6AF6BAgTEAI\#v=onepage $\& q=$ on $\% 20$ farm $\% 20$ maize $\% 20$ drying $\% 20 \mathrm{an}$ d\%20storage $\% 20 \mathrm{in} \% 20 \mathrm{hu} \% 20 \mathrm{mid} \% 20$ tropics $\% 2 \mathrm{C} \% 20 \mathrm{FAO} \% 20$ Agricultural $\%$ 20bulletin $\% 2040 \& \mathrm{f}=$ false

FAO (2018). Seeds Toolkit -Module 6 Seed Storage, Rome pp 112. Retrieved from http://www.fao.org/3/ca1495en/CA1495EN.pdf

Fields, P. G. (1992). The control of stored products insects and mites with extreme temperatures. Journal of Stored Grain Products Research, 28, 20-22. 
Fleurat-Lessard, F. (2017). Integrated management of the risks of stored grain spoilage by seed borne fungi and contamination by storage mould mycotoxins- An update. Journal of Stored Product Research, 71, 22-40. https://doi.org/10.1016/j.jspr.2016.10.002

General Survey (March 2020). Agricultural Situation in India, Directorate of Economics and Statistics, Ministry of Agriculture- DACNET. 76, (12), 15. Retrieved from https://eands.dacnet.nic.in

Global Hunger Index (2019). Peer reviewed annual report. Publisher- Concern Worldwide and Welthungerhlife. Retrieved from https://www.globalhunger index.org

Global Hunger Index (2020). Peer reviewed annual report. Publisher- Concern Worldwide and Welthungerhlife. Retrieved from https://www.globalhungerindex.org

Hage-Hamsten, M.van., \& Johansson, S. G. O. (1992). Storage mites. Experimental and Applied Acarology,16, 117-128.

Hagstrum, D. W., \& Athanassiou, C. G. (2019). Improving stored grain product insect pest management: from Theory to Practice. Insects, 10(10), 332. https://doi.org/10.3390/insects10100332

Hagstrum, D. W., \& Milliken, G. A. (1988). Quantitative analysis of temperature, moisture and diet factors affecting insect development. Annals of Entomological Society of America, 81, 539- 546.

Hagstrum, D. W., \& Subramanyam, B. (2009). Stored product insect resource. American Associate of Cereal Chemist International, USA. Retrieved from https://g.co/kgs/BGwGf6

Hall, C. W. (1980). Drying and storage of Agricultural crops. The AVI Publishing Company Inc. Connecticut, USA. https://doi.org/10.1002/food.19820260613

Hellavang, K. J. (1990). Crop storage management. NDSU Extension Service. North Dakota, USA. Retrieved from https://library.ndsu.edu/ir/bitstream/10365/17249/ 1/AE-791-1990.pdf

Honet, A., Jorosik, V., Martinkova, Z., \& Novak, I. (2002). Food induced variation of thermal constants of development and growth of Autographagamma (Lepidoptera: Noctuidae) larva. European Journal of Entomology, 99, 241- 252.

Hubert, J., Stejskal, V., Athanassiou, C. G., \& Throne, J. E. (2018). Health hazards associated with arthropod infestation of stored products. Annual Review of Entomology, 63, 553-573. https://doi.org/10.1146/annurev-ento-020117-043218

Jones, D. D., \& Shelton, D. P. (1994). "G94-1199 Management to Maintain Stored Grain Quality" (1994). Historical Materials from University of NebraskaLincoln Extension. Paper 595.http://digitalcommons.unl.edu/extensionhist/595 
Khare, B. P. (1994). Pests of stored grain and their management. Kalyani Publishers, New Delhi, India.

Kumar, D. \& Kalita, P. (2017). Reducing postharvest losses during storage of grain crops to strengthen food security in developing countries. Foods, 6(1), 8. https://doi.org/10.3390/foods6010008

Kuzmanov, D., \& Dimitrov, N. (2009). Forecasting the necessity of grain fumigation during storage. Czech Journal of Food Sciences, 27(3), 210-215.

Maity, A., Mukherjee, A., Ray, M., Pramanik, P., Parmar, S. S. Manjunatha, S. K., Wasnik, V. K. \& Kumari, S. (2020). Evaluation of seed or grain storage technologies from Indian farming societies using a hybrid and multi-attribute approach. Retrieved from https://doi.org/10.1101/2020.06.25.172189

Malek, M. A., Gatzwieler, F. W., Braun, J. V. (2017). Identifying technology innovations for marginalized smallholders - A Conceptual Approach. Technology in Society, 49, 48-56.

Mani, S., Muir, W. E., Jayas, D. S. \& White, N. D. G. (2001). Computer modelling of insect- induced hot spots in stored wheat. Canadian Biosystems Engineering, 43, 51- 64 .

Mishra, A., Prabuthas, P. \& Mishra, H. N. (2012). Grain storage: methods and measurements. Quality Assurance and Safety of Crops and Food, 4(3), 144. https://doi.org/10.1111/j.1757-837X.2012.00151.X

National Academy of Agricultural Sciences - Report 2019, 2020. Retrieved from http://www.nasonline.org

Navarro, S. (2012). Advanced grain storage methods for quality preservation and insect control based on aerated or hermetic storage and IPM. J. of Agric. Eng. 49(1),13-20. Retrieved from https://isae.in/uploads/jae-aet/16176935981320.pdf

Naveena, N. L., Subramanya, S., Setty, S., Palanimuthu, V. (2017). Grain Storage Losses in the Traditional Tribal Settlements of Biligirirangana Hills, Karnatka, India, Journal of Asia-Pacific Entomology, 20, 678-685. https://doi.org/10.1016/ j.aspen.2017.04.002

Nayak, M. K. (2006). Psocid and mite pests of stored commodities: Small but formidable enemies (pp 1061- 1073). Proceedings of $9^{\text {th }}$ International Working Conference on Stored Products Protection. Retrieved from https://www.researchgate.net/publication/228809285_Psocid_and_mite_pests_o f_stored_commodities_Small_but_formidable_enemies

Noyes, R., Navarro, S., \& Armitage, D. (2001). Supplemental aeration system. In S. Navarro \& R. Noyes (Eds) The Mechanics and Physics of Modern Grain Management. (pp.413-488). CRC Press. Boca Raton, USA. 
Piotrowska, M. Slizewska, K., \& Biernasiak, J. (2013). Mycotoxins in cereal and soybean-based food and feed. In H. El-Shemy (Ed) Soybean-Pest resistance. Intech open. https://doi.org/10.5772/54470

Procter, D. L. (1994). Grain storage techniques: Evolution and Trends in developing countries. FAO Agricultural Services Bulletin no 109, Rome, Italy. https://g.co/kgs/xovXPa

Pruthi, H. S. \& Singh, M. (1950). Pests of stored grain and their control. Indian Journal of Agricultural Sciences, 18, 1-52.

Said, P. P. \& Pradhan, R. C. (2014). Food grain storage practices- A review. Journal of Grain Processing and Storage, 1(1), 1-5.

Sarma, J. S. (1978). India: A drive towards self-sufficiency in Foodgrains. American Journal of Agricultural Economics, 60, 859 - 864.

Shelton, D. P. \& Thompson, T. L., (1993). Aeration of stored grain.NDSU Extension Service, North Dakota, USA. Retrieved from https://lib.ugent.be/en/catalog/ ebk01:4330000001234092.

Shelton, D. K., Jarvi, K. J., \& Jones, D. (1998). Initial grain condition determines quality of stored grain. Neb GUIDE, University of Nebraska Cooperative Extension Service. 3, Nebraska.

Sinha, R. N., \& Wallace, H. A. (1966). Ecology of insect- induce hot spots in stored grain in Western Canada. Res. Population. Ecology, 8, 107-132.

Sisman, C. B. (2003). Storage of the Grain. Turk-Koop Ekin, 7(25), 73-77.

Sisman, C. B. (2005). Quality losses in temporary sunflower seeds storage and influences of storage conditions on losses during storage. Journal of Central European Agriculture, 6(2), 143-150.

Sisman, C. B., \& Delibas, L. (2005). Storing sunflower seeds and quality losses during storage. Journal of Central European Agriculture, 5(4), 239-250.

Smith, R. H. (1994). Rodents and birds as invaders of stored grain ecosystem. Stored grain ecosystems, 289- 323. (Ed) Jayas, D. S., Noel, D. G., \& Muir, W. E. Publisher CRC press.

Srivastava, C., \& Subramanian, S. (2016). Storage insect pests and their damage symptoms: An overview. Indian Journal of Entomology, 78 (Special), 53. DOI: $\underline{10.5958 / 0974-8172.2016 .00025 .0}$

Stejskal, V., Aulicky, R., \& Kucerova, Z. (2014). Pest control strategies and damage potential of seed-infesting pests in Czechoslovakia stores- Plant Protection Science, 50, 165-173. https://doi.org/10.17221/10/2014-PPS 
Stejskal, V., Hubert, J., Aulicky, R., \& Kucerova, Z. (2015). Overview of present and past and pest associated risks in stored food and feed products: European perspective. Journal of Stored Products Research, 64, 122-132. https://doi.org/10.1016/j.jspr.2014.12.006

Stejskal, V., Vending, T., Li, Z. \& Aulicky, R. (2019). Minimal thermal required development and activity of stored products and food industry Pests (Acari, Psocoptera, Diptera and Blattodea): A review. Insect, 10(5), 149. https://doi.org/10.3390/insects10050149

Subramanyam, B., \& Hagstrum, D. W. (1993). Predicting development times of six stored-product moth species (Lepidoptera: Pyralidae) in relation to temperature, relative humidity and diet. European Journal of Entomology, 90, 52-64.

Tyagi, S. K., Guru, P. N., Nimesh, A., Bashir, A. A., Patgiri, P., Mohod, V., \& Khatar, A. B. (2019). Post-harvest stored product insects and their management. Technical Bulletin No. AICRP on PHE/Pub/2019/02. https://doi.org/10.13140/ $\underline{\text { RG.2.2.31411.78885 }}$

Vidal, P., Guaita, M., \& Aujuga, F. (2005). Analysis of dynamic Discharge pressure in cylindrical slender silos with a flat bottom or with a Hopper: Comparison with Eurocode 1. Biosystems Engineering, 91(3), 335-348.

How to cite this article: Rath, R., Saxena, R., Sood, N., \& Gupta, S. (2021). Safe grain storage- post harvest technology: An Indian perspective. Vantage: Journal of Thematic Analysis, 2(2):

DOI: https://doi.org/10.52253/vjta.2021.v02i02.04

(C) The Author(s) 2021.

This work is licensed under a Creative Commons Attribution 4.0 International License which permits its use, distribution and reproduction in any medium, provided the original work is cited. 